\title{
Senates, Unions, and the Flow of Power in American Higher Education*
}

\author{
FRANK R. KEMERER**
}

\begin{abstract}
This article draws on longitudinal survey research to examine the influence profiles of senates standing alone on college campuses in the United States, as well as the influence profiles of coexisting senates and faculty unions. The article discusses the forces prompting a flow of power away from faculty deliberative bodies and speculates on the future of faculty senates as hard times came to American higher education.
\end{abstract}

\section{RÉSUMÉ}

Cet article essaie de retracer l'influence des "sénats académiques" dans les institutions où il n'existe pas de syndicats de professeurs et d'en faire une comparaison avec les institutions où les deux corps doivent coexister. L'auteur discute des forces qui tendent à diminuer l'influence des assemblées délibérantes et du sort que pourrait leur réserver la période difficile que l'enseignement postsecondaire américain traverse.

Faculty unions have now become fairly well entrenched in American higher education. There are now nearly 700 unionized campuses in the United States, up from 160 in 1970 . More than one out of every four faculty and professional staff members in the country has joined a union. Questions continually arise about the impact of faculty collective bargaining on faculty senates. Have unions undercut the power of these deliberative bodies or have they enhanced it? Complicating the situation somewhat is a steady flow of power off campus to centralized agencies. Enrollment declines have also contributed to a flow of power away from faculty deliberative bodies.

* This article is an expanded version of a presentation delivered at the annual conference of the Canadian Society for the Study of Higher Education in 1982 at the University of Ottawa.

** Professor of Education Law and Administration, North Texas State University 
This paper briefly reviews the health of academic senates in American higher education. It looks at both the impact of collective bargaining and the effect of changing external conditions on faculty governance patterns.

\section{RESEARCH BACKGROUND}

The initial research on academic governance was conducted as part of the Stanford Project on Academic Governance, a major research project conducted in two phases and funded by the federal government's National Institute of Education. The 1971 phase was concerned with general governance issues at 240 representative institutions. The second phase was conducted in 1974, and the prime focus was on collective bargaining. Dr. J. Victor Baldridge, Senior Research Sociologist at UCLA's Higher Education Research Institute, and I resampled the presidents at the mostly non-unionized 240 institutions and added all presidents and faculty union chairpersons at unionized schools in the United States. The overall response rate was 65 percent. Six case studies were also included. The results of these two phases are detailed in Kemerer and Baldridge (1976) and Baldridge, et al (1978).

From 1977 to 1980 we conducted an extension of the earlier project. The 1979 questionnaire survey was especially designed as a follow-up to the 1974 survey. We realized that we had a unique opportunity to secure longitudinal data about institutional governance and we wished to take advantage of it. Again we surveyed the presidents of the original 240 institutions from the 1971 phase. We also surveyed all the unionized campuses in the nation, questioning the presidents and local faculty union chairpersons. The overall response rate was 52 percent. Case studies were once again included as part of the research. The results are described in detail in Baldridge and Kemerer (1981).

From 1980 to 1982 we shifted our research focus to enrollment management issues. In the spring and summer of 1981 we administered a survey to a representative national sample of college presidents and admissions directors with a response rate of 72 percent. We also conducted case studies around the country and directed a consortium of private colleges concerned with improving student retention. The results of this research are included in Baldridge, Kemerer, and Green (1982) and Kemerer, Baldridge, and Green (1982). The latter is directed specifically to college presidents, vice presidents, deans, and directors of admissions.

This research coupled with a continuous monitoring of the available literature provides the basis for the ensuing discussion.

\section{THE POWER PROFILE OF FACULTY SENATES}

In what areas do faculty senates have influence where they exist without the presence of a faculty union? To obtain some baseline data on the influence profile of faculty senates, we asked a nationally representative sample of campus presidents at institutions without faculty unions in 1974 to indicate the influence levels of the faculty deliberative body on their campus. The results are portrayed in Table 1 . 
Table 1: Presidents " ${ }^{\star}$ Perceptions of Senate Influence on

\begin{tabular}{|c|c|c|c|c|c|c|c|c|}
\hline & Curriculum & $\begin{array}{l}\text { Degree } \\
\text { Require- } \\
\text { ments }\end{array}$ & $\begin{array}{l}\text { Long- } \\
\text { Range } \\
\text { Planning }\end{array}$ & $\begin{array}{l}\text { Admissions } \\
\text { Policy }\end{array}$ & $\begin{array}{l}\text { Faculty Pro- } \\
\text { motion and } \\
\text { Tenure } \\
\text { Policies }\end{array}$ & $\begin{array}{l}\text { Dept. } \\
\text { Budgets }\end{array}$ & $\begin{array}{l}\text { Faculty } \\
\text { Hiring } \\
\text { Policies }\end{array}$ & $\begin{array}{c}\text { Faculty Salaries } \\
\text { and } \\
\text { Fringe Benefits }\end{array}$ \\
\hline $\begin{array}{l}\text { Public and } \\
\text { Private } \\
\text { Multiuni- } \\
\text { versities } \\
(N=11)\end{array}$ & 3.3 & 3.0 & 3.1 & 2.6 & 3.4 & 1.2 & 2.5 & 2.0 \\
\hline $\begin{array}{l}\text { Public } \\
\text { Coll eges } \\
\text { and Uni- } \\
\text { versities } \\
(N=26)\end{array}$ & 4.1 & 3.9 & 3.1 & 3.0 & 3.8 & 2.0 & 2.6 & 2.5 \\
\hline $\begin{array}{l}\text { Private } \\
\text { Liberal } \\
\text { Arts } \\
\text { Colleges } \\
(N=50)\end{array}$ & 4.4 & 4.4 & 3.1 & 3.1 & 3.0 & 2.0 & 2.8 & 2.0 \\
\hline $\begin{array}{l}\text { Public and } \\
\text { Private } \\
\text { Two-Year } \\
\text { Colleges } \\
(\mathrm{N}=22)\end{array}$ & 3.6 & 3.6 & 3.0 & 2.4 & 2.6 & 2.3 & 2.7 & 2.7 \\
\hline
\end{tabular}

Note: The question asked was "How much influence does the faculty senate have on these issues at your institution?" The respondents gave answers on a five-point scale, with "1" indicating low influence and "5" indicating high influence.

* By 1974, 29 of the 240 institutions included in the original 1971 sample of nonunionized campuses had unions. This left 211. Of these, a handful did not have such a representative body on campus. Thus, the 109 respondents above represent about 65 percent of the total surveys administered. 
Table 1 shows that senates at all four types of institutions have remarkably similar profiles. Senates appear to be the most influential over academic issues and least influential over economic matters such as faculty salaries, department budgets, and faculty workload.

A word of caution is in order. Survey results reflect presidential perceptions. Presidents may have over-estimated the influence of faculty deliberative bodies or they may have under-estimated it. We know from other studies conducted about the same time that faculty senate power tends to be moderate at best. For example, a 1971 study of institutions with member chapters by the American Association of University Professors found limited faculty participation in governance. Both chief administrative officers and chapter presidents in the AAUP study tended to categorize faculty participation as "discussion" or "consultation." Neither could claim joint participation with the administration in campus decision making. This lack of effectiveness was particularly true in terms of economic and personnel issues. (Garbarino, 1975, Chapter Three). Our 1974 survey of faculty union chairpersons revealed that desire for more governance influence on their campus was a significant reason for the presence of faculty collective bargaining. (Kemerer and Baldridge, 1976, pp. 40-41, 57-60). It would appear that faculty members turn to unions especially for help in influencing decisions about economic matters. There are bread-and-butter issues for unions and, as we have seen, generally beyond the influence sphere of faculty senates.

\section{SENATES AND UNIONS EXISTING TOGETHER}

\section{Survey Results}

Recall that in addition to a representative sample of presidents at non-unionized campuses, we surveyed all the presidents and faculty union chairpersons at unionized campuses in 1974. One of the questions invited them to chart the influence profile of the senate and of the union on their campuses. Before we look at the results, a caveat is in order. In the United States, faculty unionization is concentrated primarily among the less prestigious institutions - community colleges, public four-year colleges, and weaker private liberal arts colleges. These are the very institutions where faculty participation in governance has been weakest. Faculty members at institutions with a long history of strong governance influence such as Harvard, Stanford, and the University of California at Berkeley, have not embraced faculty collective bargaining. Indeed, the 1980 decision by the U.S. Supreme Court in the NLRB $v$. Yeshiva University case has virtually halted unionization at private colleges and may have a spillover effect at public institutions. The Supreme Court ruled in Yeshiva that if the faculty play a substantial role in governance, they are managers under the National Labor Relations Act and precluded from bargaining. The decision involves only the federal law and private colleges. Collective bargaining at public colleges is determined by state collective bargaining laws. To date slightly over half the 50 states have 
extensive enabling legislation. Aside from California where unionization of community colleges and the state university system is now taking place, little unionization is occurring, in large part because of the absense of enabling legislation in many states. In the public sector there is a tendency to model collective bargaining procedures and practices on the federal model, hence the possible carryover effect of Yeshiva. (For an analysis of the Yeshiva case, see Clarke, 1981, and Zirkel, 1981).

Our research, therefore, as presented in Table 2 sheds light on what happens to weak senates when unionization occurs; but it does not tell us much about the impact of unions coexisting with strong faculty governance bodies.

Table 2 reveals several interesting things about coexisting senates and unions at four-year campuses. Let us enumerate them for sake of clarity

1. The ratings of presidents and union chairpersons are basically similar. This is especially interesting, given their quite different perspectives.

2. Unions clearly outperform senates in influencing economic issues, particularly faculty salaries and working conditions. Since both are prime bargaining topics, this isn't surprising.

3. Senates retain moderate influence over academic issues.

4. Senates and unions share influence over personnel issues such as faculty hiring, promotion, and tenure policy.

5. Neither senates nor unions influence departmental budgets.

6. Unions have little influence over long-range planning; senates have some.

What these data indicate is the emergence of a dual track, where senates retain influence over academic matters while unions dominate over economic issues when the two bodies coexist on the same campus. While not shown in the data presented here, we also found that the influence profile of unions where they exist in the absence of senates is similar to that of the profile presented in Table 2 and that the influence profiles of senates and unions coexisting at community colleges differ little from those at four-year campuses. When checked against the content of union contracts, the pattern remained the same. Contracts essentially dealt with working conditions, not academic matters. (Andes, 1974).

We predicted in our 1976 book, Unions on Campus, that the competitiveness of unions, coupled with the well-known tendency for contracts to expand over time, posed a direct threat to peaceful coexistence of faculty senates and unions on the same campus. While we did not forecast an end to deliberative bodies, we were frankly skeptical about the continued viability of the dual track. Thus, we were curious to learn more about the health of the faculty senate at unionized institutions through our 1979 follow-up survey.

\section{Survey Results}

Table 3 charts the influence of coexisting senates and unions at four-year campuses. Note that only campuses with a collective bargaining contract prior to 1975 are included in Table 3 so as to approximate the 1974 group. We are thus 
Table 2: Influence of Coexisting Senates and Unions at Four-Year Campuses in 1974

\begin{tabular}{|c|c|c|c|c|c|c|c|c|c|}
\hline & Curriculum & $\begin{array}{l}\text { Degree } \\
\text { Require- } \\
\text { ments }\end{array}$ & $\begin{array}{l}\text { Long } \\
\text { Range } \\
\text { Planning }\end{array}$ & $\begin{array}{l}\text { Admissions } \\
\text { Policy }\end{array}$ & $\begin{array}{l}\text { Faculty } \\
\text { Promotion } \\
\text { and Tenure } \\
\text { Policies }\end{array}$ & $\begin{array}{l}\text { Dept. } \\
\text { Budgets }\end{array}$ & $\begin{array}{l}\text { Faculty } \\
\text { Hiring } \\
\text { Policies }\end{array}$ & $\begin{array}{l}\text { Faculty } \\
\text { Working } \\
\text { Condi- } \\
\text { tions }\end{array}$ & $\begin{array}{l}\text { Faculty } \\
\text { Salaries and } \\
\text { Fringe } \\
\text { Benefits }\end{array}$ \\
\hline \multicolumn{10}{|l|}{$\begin{array}{l}\text { Presidents } \\
(N=59)\end{array}$} \\
\hline $\begin{array}{l}\text { Senates } \\
\text { Unions }\end{array}$ & $\begin{array}{l}4.2 \\
1.7\end{array}$ & $\begin{array}{l}3.9 \\
1.5\end{array}$ & $\begin{array}{l}3.2 \\
1.9\end{array}$ & $\begin{array}{l}2.9 \\
1.3\end{array}$ & $\begin{array}{l}3.1 \\
2.9\end{array}$ & $\begin{array}{l}1.9 \\
1.6\end{array}$ & $\begin{array}{l}2.5 \\
2.3\end{array}$ & $\begin{array}{l}2.2 \\
2.8\end{array}$ & $\begin{array}{l}1.5 \\
4.1\end{array}$ \\
\hline \multicolumn{10}{|l|}{$\begin{array}{l}\text { Union Chair- } \\
\text { persons } \\
(N=56)\end{array}$} \\
\hline $\begin{array}{l}\text { Senates } \\
\text { Unions }\end{array}$ & $\begin{array}{l}3.8 \\
1.8\end{array}$ & $\begin{array}{l}3.7 \\
1.5\end{array}$ & $\begin{array}{l}2.6 \\
2.4\end{array}$ & $\begin{array}{l}2.5 \\
1.4\end{array}$ & $\begin{array}{l}3.7 \\
.37\end{array}$ & $\begin{array}{l}1.5 \\
1.4\end{array}$ & $\begin{array}{l}1.8 \\
2.7\end{array}$ & $\begin{array}{l}1.6 \\
3.7\end{array}$ & $\begin{array}{l}1.3 \\
4.7\end{array}$ \\
\hline
\end{tabular}

Note: The questions was "How much influence does the faculty union and senate have on these issues at your

institution?" The respondents gave answers on a five-point scale with "l" indicating low influence and "5"

indicating high influence. The figures in Table 2 represent grouped responses; they do not match presidents and chairpersons from the same campuses. 
Table 3: Influence of Coexisting Senates and Older Unions at Four-Year Campuses: 1974 and 1979 Contrasted

\begin{tabular}{|c|c|c|c|c|c|c|c|c|c|c|c|c|c|c|c|c|c|c|}
\hline & \multicolumn{2}{|c|}{ Curricutum } & \multicolumn{2}{|c|}{$\begin{array}{l}\text { Degree } \\
\text { Require- } \\
\text { ments }\end{array}$} & \multicolumn{2}{|c|}{$\begin{array}{l}\text { Long- } \\
\text { Range } \\
\text { Planning }\end{array}$} & \multicolumn{2}{|c|}{$\begin{array}{l}\text { Admissions } \\
\text { Policy }\end{array}$} & \multicolumn{2}{|c|}{$\begin{array}{l}\text { Faculty } \\
\text { Promotion } \\
\text { and Tenure } \\
\text { Policies }\end{array}$} & \multicolumn{2}{|c|}{$\begin{array}{l}\text { Dept. } \\
\text { Budgets }\end{array}$} & \multicolumn{2}{|c|}{$\begin{array}{l}\text { Faculty } \\
\text { Hiring } \\
\text { Policies }\end{array}$} & \multicolumn{2}{|c|}{$\begin{array}{l}\text { Faculty } \\
\text { Working } \\
\text { Conditions }\end{array}$} & \multicolumn{2}{|c|}{$\begin{array}{l}\text { Faculty } \\
\text { Salaries } \\
\text { and Fringe } \\
\text { Benefits }\end{array}$} \\
\hline & 1974 & 1979 & 1974 & 1979 & 1974 & 1979 & 1974 & 1979 & 1974 & 1979 & 1974 & 1979 & 1974 & $\overline{979}$ & 1974 & 1979 & 1974 & 1979 \\
\hline \multicolumn{19}{|l|}{$\begin{array}{r}\text { Presidents } \\
(N=59 / 43)\end{array}$} \\
\hline $\begin{array}{l}\text { Senates } \\
\text { Unions }\end{array}$ & $\begin{array}{l}4.2 \\
1.7\end{array}$ & $\begin{array}{l}4.3 \\
1.6\end{array}$ & $\begin{array}{l}3.9 \\
1.5\end{array}$ & $\begin{array}{l}4.9 \\
1.4\end{array}$ & $\begin{array}{l}3.2 \\
1.9\end{array}$ & $\begin{array}{l}3.4 \\
1.9\end{array}$ & $\begin{array}{l}2.9 \\
1.3\end{array}$ & $\begin{array}{l}3.0 \\
1.2\end{array}$ & $\begin{array}{l}3.1 \\
2.9\end{array}$ & $\begin{array}{l}2.7 \\
3.2\end{array}$ & $\begin{array}{l}1.9 \\
1.6\end{array}$ & $\begin{array}{l}1.5 \\
1.4\end{array}$ & $\begin{array}{l}2.5 \\
2.3\end{array}$ & $\begin{array}{l}2.0 \\
2.5\end{array}$ & $\begin{array}{l}2.2 \\
2.8\end{array}$ & $\begin{array}{l}1.7 \\
3.5\end{array}$ & $\begin{array}{l}1.5 \\
4.1\end{array}$ & $\begin{array}{l}1.4 \\
4.7\end{array}$ \\
\hline \multicolumn{19}{|c|}{$\begin{array}{l}\text { Union chair- } \\
\text { persons } \\
(N=56 / 48)\end{array}$} \\
\hline $\begin{array}{l}\text { Senates } \\
\text { Unions }\end{array}$ & $\begin{array}{l}3.8 \\
1.8\end{array}$ & $\begin{array}{l}4.0 \\
1.7\end{array}$ & $\begin{array}{l}3.7 \\
1.5\end{array}$ & $\begin{array}{l}3.7 \\
1.6\end{array}$ & $\begin{array}{l}2.6 \\
2.4\end{array}$ & $\begin{array}{l}3.2 \\
2.3\end{array}$ & $\begin{array}{l}2.5 \\
1.4\end{array}$ & $\begin{array}{l}2.6 \\
1.3\end{array}$ & $\begin{array}{l}2.7 \\
3.7\end{array}$ & $\begin{array}{l}2.3 \\
3.7\end{array}$ & $\begin{array}{l}1.5 \\
1.4\end{array}$ & $\begin{array}{l}1.6 \\
1.5\end{array}$ & $\begin{array}{l}1.8 \\
2.7\end{array}$ & $\begin{array}{l}2.0 \\
2.9\end{array}$ & $\begin{array}{l}1.6 \\
3.7\end{array}$ & $\begin{array}{l}1.7 \\
3.8\end{array}$ & $\begin{array}{l}1.3 \\
4.7\end{array}$ & $\begin{array}{l}1.2 \\
4.5\end{array}$ \\
\hline
\end{tabular}

NOTE: The questions was: "How much influence does the faculty union and senate have on these issues at your institution?" The respondents gave answers on a five-point scale, with " 1 " indicating low influence and "5" indicating high influence. Only campuses with a collective bargaining contract prior to 1975 are included from the 1979 survey so as to approximate

the 1974 group. The figures in Table 3, like those in Table 2, represent grouped responses; they do not match presidents and chairpersons from the same campuses. 
looking at campuses where the senate - union relationship has been well established. This is essential for longitudinal data purposes. In effect, we are taking another snapshot five years later of the senate and union profiles at campuses with a history of collective bargaining. For comparison purposes, the 1974 ratings from Table 2 have been repeated in Table 3 .

Table 3 shows that the dual track has not deteriorated over time. Indeed, the demarcations between senate and union influence appear clearer now than in 1974. Note that presidents see the influence of senates increasing in several areas, especially degree requirements. At the same time they view union influence over economic issues, especially faculty working conditions and promotion/tenure policies to have increased. Union? chairpersons see senate power increasing slightly in some areas but note little change in union influence. Again, there is remarkable consistency in the views of presidents and chairpersons despite their differing perspectives.

Neither unions nor senates are perceived by either respondent group as having much influence over long range planning, though presidents see senates having slightly more influence in this area in 1979 than in 1974.

Though not shown in Table 3 , the senate-union relationship at two-year campuses with a history of bargaining is quite similar. The one significant exception concerns the views of union chairpersons regarding the influence of the union. They view the union as losing influence in all areas since 1974, possibly the result of union inability to do much about general economic conditions, budget-cutting by local and state governments, and enrollment decline.

At both four-year and two-year campuses, union influence is highest over salary issues. Salary matters are, of course, mandatory bargaining topics. It is usually an unfair labor practice for management to refuse to negotiate salary levels. Given the depressed economic conditions in the United States, faculty members are now most concerned with their paychecks. Otherwise, the influence of both unions and senates tends to be moderate or low. Certainly some matters such as department budgets are the prerogative of these units. And certainly administrators retain considerable authority to make decisions. Insofar as bargaining is concerned, there is mounting evidence that administrators are less fearful now of faculty collective bargaining than in 1974. The percentage of presidents at unionized campuses who see bargaining decreasing their power has declined from 41 percent in 1974 to 34 percent in 1979, while those seeing their power increasing has risen from 14 to 23 percent. As in 1974,45 percent report no change. At the same time, the percentage of presidents who see collective bargaining increasing faculty influence has declined from 37 to 29 percent, while the percentage reporting the opposite effect has nearly doubled.

An analysis of collective bargaining contracts confirms the fact that governance provisions continue to be limited in scope. For example, in a special study conducted at our request, Professor John Andes at West Virginia University found the percentage of contracts mentioning the senate had increased from 7 to 10 percent in 1979. Where governance provisions are included, most often they 
incorporate provisions from faculty handbooks, AAUP policy statements, and the like.

\section{THREATS TO THE POWER OF FACULTY SENATES}

Are unions likely to undermine continued viability of the dual track in the future? Are there other threats to traditional faculty governance bodies which may shift power away from the faculty? This section explores these questions.

\section{How Stable is the Dual Track?}

Several factors are responsible for continued viability of the dual track. First, the legal framework has worked to confine bargaining topics to traditional economic matters. This limits the ability of union leaders to enfranchise the faculty with governance power on campuses where the pattern has been one of strong administrative authority. It also affords administrators with the means to thwart union attempts to undercut faculty deliberative bodies where they exist. Deliberative bodies provide administrators with useful forums outside of the bargaining arena to discuss a variety of important academic issues. Of course, if administrators believe that the senate is merely the union wearing a different hat, they may cease to support senates. However, on many campuses, the union membership consists of less than a majority of the faculty. In the United States, union security agreements in the form of union or agency shops are by no means universal. In some states, they are even prohibited by law. Where this is the case, union interests are not always the same as senate interests because of differences in membership.

But even if the membership of a faculty union perfectly overlaps that of the senate, it seems unlikely that the faculty members themselves on very many campuses would willingly allow the union to destroy the senate and replace it with a union-controlled body. Why is this so? Ladd and Lipset offered a hypothesis in 1973 to the effect that faculty members at prestigious institutions are torn between their pro-union views and their academic values, opting in the end not to join unions. (1973, pp. 22-33). It is likely that a version of this hypothesis is a powerful reason for the continued stability of the dual track. Even when academicians join unions, their professional commitments are often sufficiently strong to restrain the union from encroaching on senate and department territory. At the same time, by incorporating prior arrangements, collective bargaining agreements provide a degree of security not present at the non-unionized institution where faculty governance influence usually depends on administrative willingness to share authority. Since two-year faculty members in many cases are trying to secure the professional prerogatives of four-year graduate school faculty, and the latter are trying to prevent their erosion, it is unlikely that most faculty unions will be quick to negotiate faculty rights away. Indeed, when asked in the 1979 survey if the faculty union had undermined the faculty senate or other established decision body, nearly 70 percent of the faculty union chairpersons said no or reported no change. 


\section{Collective Bargaining Increases Administrative Power}

As noted above, campus presidents are less fearful of collective bargaining now than when it first surfaced. They are gradually seeing that bargaining may actually be one way of increasing administrative power. How can bargaining increase administrative power?

First, there usually is an increase in the number of administrators. To conduct collective bargaining successfully, a cadre of administrative specialists is needed - personnel administrators, labor relations experts, lawyers, computer analysists. Both in 1974 and in 1979 , over 80 percent of presidents at unionized campuses said collective bargaining had increased the need for specialists on their campus. Over 50 percent of faculty union chairpersons agreed in both surveys. In both 1974 and 1979 , roughly two-thirds of presidents at unionized campuses and onethird of faculty union chairpersons said they expected the specialists to replace generalists in campus administration.

New administrators are also added when department chairpersons and other administrators are included in the faculty bargaining unit. Richardson and Mortimer found "a third echelon of key administrators with the title of dean was emerging .... Staff positions previously titled dean had been changed to vice president, thus strengthening and, in many instances, expanding the numbers and levels of key administrators" (1978, p. 339).

Faculty collective bargaining stimulates adding new management tools such as a management information system, because negotiations cannot be effectively conducted without abundant information about institutional economics. These management tools frequently are important sources of new administrative power.

Administrators are also gaining power by perceiving collective bargaining as a two-way street. They do not hesitate to mount an aggressive management position, demanding important trade-offs in return for desired benefits. The tough management position at the University of Hawaii system in the early stages of bargaining proved to be a decided setback to faculty unionization there. The aggressive bargaining position of the Office of Employee Relations in New York has prevented the State University of New York faculty union from getting many governance-related items into the contract.

\section{Enrollment and Fiscal Problems Shift Power to Administrators}

The enrollment crisis on many campuses whether unionized or not is another factor promoting the flow of power upward to administrators. Using the 1979-82 years as a baseline for peak enrollments, the Carnegie Council projects a 15 percent decline in FTE enrollments between 1983 and 1996 (a conservative estimate by some estimates), a loss of 1.35 million FTE students. (Carnegie Council, 1980, Chapter Three). The Carnegie Council estimates that 40 percent of this decline will occur by 1989 , a drop of approximately 540,000 FTE students. (For a complete discussion of enrollment projections in American higher education, see Baldridge, Kemerer, and Green, 1982, pp. 4-15). Many campuses have already 
experienced enrollment shortfalls, especially among the less prestigious private colleges.

When enrollment and fiscal problems threaten to overwhelm a campus, response time is limited. Administrators need to make decisions quickly and often employ sophisticated management tools in the process. For example, many campuses have developed management information systems to monitor costs and project future enrollment and fiscal trends. Rarely does the information these systems produce get back to the faculty.

Baldridge and Tierney concluded in a recent study of campuses implementing new management techniques that "many management innovations will tend to centralize authority, since information and planning may be centered in a few hands. Thus, it was disconcerting to find that faculty members, in particular, felt that power and authority on the project campuses were increasingly concentrated in the hands of project administrators" (1979, p. 10). George Keller, author of a forthcoming book entitled Academic Strategy: Planning and the New Management Style in American Higher Education, observed in a recent article that "Those famous debating societies, the faculty senates, are crumbling. Many of them have trouble getting a quorum for votes; even the American Association of University Professors acknowledges their gradual demise. And AAUP leaders are worrying about how to continue to protect precious faculty prerogatives in the coming decade." (Keller, 1982, p. 3). Our 1981 enrollement survey of campus presidents revealed that roughly half agree with the statement "The faculty here has only a perfunctory role in the preparation of the annual budget." Considering that the budget process is a key decision-making event, especially in these difficult times, such a large positive response to that question certainly testifies to weaknesses in the shared governance concept.

While we assert in our enrollment management publications that the faculty should be involved in enrollment management efforts, our case study research clearly demonstrates that most often administrators run the show. (Kemerer, Baldridge, and Green, 1982).

\section{Power in Multicampus Systems is Being Centralized}

While administrators may gain influence, not all gain equally. Campus presidents in multicampus systems see system administrators and state agencies gaining power at their expense. Centralization of power off-campus is also a major threat to faculty power.

The organization of individual campuses into multicampus systems is, of course, restricted primarily to the public sector. Most states exercise limited control over private institutions, which together enroll only about one-fifth of all the students in higher education. Public multicampus systems have grown rapidly. By the early 1970 s nine statewide multicampus systems enrolled a quarter of all students in public four-year colleges and universities. Today, this figure is even higher. The Education Commission of the States reports that there are currently over 350 multicampus systems ranging from small systems of only a 
few campuses to those which are statewide. Interestingly, Mayhew (1977) notes that as of the mid-1970s "only four states persisted in the historic practice of allowing each individual campus to be governed by a single board of trustees, having direct and unrestricted access to the governor and the legislature" (p. 223).

Three-quarters of the campus presidents in our 1979 survey agreed that system management is continually increasing. Presidents on campuses in unionized systems are particularly concerned with the erosion of local campus decision rights, in large part because unionization itself promotes centralization. In the overwhelming number of cases, the faculty in a state university system have been combined in a single system-wide bargaining unit, implying that their work conditions should be jointly - and centrally - determined. Thus, system administrators usually play an important role in contract negotiation and in some systems such as the State University of New York, the state executive branch controls the management side of the bargaining table. Other state agencies stand to gain, such as public employee relations boards (PERBs), funding agencies, arbitrators, and courts. In short, bargaining promotes a whole range of new power centers at the state level.

\section{Statewide Agencies Exert Greater Control}

In addition, virtually every state now has some superinstitutional control, ranging from weak planning agencies to statewide governing boards covering all public postsecondary education. Approximately three-fifths of the states employ coordinating boards, which until the mid-1970s had limited influence over campus affairs. State coordinating bodies stand mid-way between voluntary consortia and consolidated governing boards.

By the end of the decade, state coordinating boards began to play a larger role in higher education. One of the strongest is the New York State Board of Regents. The Board has, for example, effectively asserted power to control doctoral degree programs at the State University of New York. The issues over which most state boards are gaining control include responsibility for systematic data-gathering and analysis, planning, licensing of new institutions, approval of new degrees, evaluation of existing programs, termination of unnecessary programs, administration of state and federal aid programs, and budgetary review.

There are presently twenty consolidated governing boards, which in effect are simply statewide multicampus systems. Eleven of them - Alaska, Georgia, Hawaii, Maine, Montana, North Dakota, Rhode Island, Utah, West Virginia, and Wisconsin - have responsibility for virtually all of public higher education. Nine others Arizona, Florida, Idaho, Oregon, Iowa, Kansas, Mississippi, North Carolina, and South Dakota - have responsibility for senior institutions only. (South Dakota is unique because the state has no community colleges.) In each of these states, the powers and responsibilities of the governing boards differ, but the basic trend of strong control is present.

Respondents to our 1979 survey clearly perceive that power is moving off camps toward centralized agencies. Over 60 percent of the presidents at unionized 
campuses, 44 percent of faculty union chairpersons, and 33 percent of presidents at non-unionized campuses agreed with the statement "there has been a strong move to remove important decisions from our local campus and put them at the state level." Presidents on campuses in unionized systems of education were particularly concerned - 67 percent agreed. Institutional type did not have a significant influence in the pattern of responses - community college people were as concerned as those at four-year and graduate institutions, though respondents at private institutions were somewhat less concerned.

In a recent presentation to an AAUP-sponsored conference on faculty governance, Professor Robert Berdahl of the University of Maryland observed that of the twenty-eight states with coordinating boards, only three have faculty advisory committees; of the twenty states with consolidated governing boards, only seven have equivalently broad-based faculty senates (Faculty Governance, 1981, p. 385). It seems clear that with the steady flow of power upward and off campus, the role of faculty deliberative bodies - and even faculty unions and campus administrators - is increasingly threatened.

\section{CONCLUSION}

The preceding discussion suggests that American higher education is presently in a state of flux. Old patterns are giving way to new as hard times take their toll. Faculty senates struggle to maintain their existence. Faculty unions struggle to preserve previous gains or to enfranchise the faculty with new power and benefits.

Unions, however, have had a difficult time making much headway. Among the public and even much of academe, unions are unpopular. They are also largely impotent in the face of demographically-induced enrollment decline and economic recession.

Our research has demonstrated that for the most part, unions have not undermined faculty deliberative bodies. If anything, they have helped protect them by incorporating prior governance arrangements into the contract. But in the process collective bargaining has pushed more power toward administrators and, in multicampus systems, off campus to centralized agencies. At the same time, the adoption of new management practices and techniques to help campuses adapt to enrollment and fiscal realities has worked to increase administrative power on and off campus, largely at the expense of faculty influence.

This isn't to say, however, that faculty influence will slowly wither away. Colleges and universities are labor intensive organizations. Administrators cannot make major decisions without securing faculty support. It is entirely likely that hard times will force a stronger partnership between the faculty and the administration on many campuses. But one wonders whether faculty influence will not tend to be more reactive than proactive in the face of power shifts upward. One also wonders whether faculty influence will continue to be exerted through traditional faculty senates. The faculty senate may no longer be a viable structure through which faculty influence can be exercised. 


\section{REFERENCES}

Andes, J. Developing Trends in Content of Collective Bargaining Contracts in Higher Education. Washington, D.C.: Academic Collective Bargaining Information Services, 1974.

Baldridge, J.V., Curtis, D.L., Ecker, G., \& Riley, G.L. Policy Making and Effective Leadership. San Francisco: Jossey-Bass, 1978.

Baldridge, J.V., \& Kemerer, F.R. Assessing the Impact of Faculty Collective Bargaining. AAHEERIC/Higher Education Research Report No. 8, 1981. Washington, D.C.: American Association for Higher Education, 1981.

Baldridge, J.V., Kemerer, F.R., \& Green, K.C. Enrollments in the Eighties: Factors, Actors, and Impacts. AAHE-ERIC/Higher Education Research Report No. 3, 1982. Washington, D.C.: American Association for Higher Education, 1982.

Baldridge, J.V., \& Tierney M.L. New Approaches to Management. San Francisco, CA: Jossey-Bass, 1979.

Carnegie Council on Policy Studies in Higher Education. Three Thousand Futures. San Francisco: Jossey-Bass, 1980.

Clarke, C.A. The Yeshiva Case. Journal of Higher Education, Vol. 52, No. 5. September/ October, 1981, 449-469.

Faculty Governance in the 80s: Adverse Conditions, Diverse Responses, Academe, Vol. 67, No. 6, 1981, 383-386.

Garbarino, J.W. Faculty Bargaining: Change and Conflict. New York: McGraw-Hill, 1975.

Keller, G. The New Management Revolution in Higher Education. AAHE Bulletin, Vol. 35 , No. 2, October, 1982, 3-5.

Kemerer, F.R., \& Baldridge, J.V. Unions on Campus. San Francisco: Jossey-Bass, 1976.

Kemerer, F.R., Baldridge, J.V., \& Green, K.C. Strategies for Effective Enrollment Management. Washington, D.C.: American Association of State Colleges and Universities, 1982.

Ladd, E.C., \& Lipset, S.M. Professors, Unions, and American Higher Education. Berkeley, Calif.: Carnegie Commission, 1973.

Mayhew, L.B. Legacy of the Seventies. San Francisco: Jossey-Bass, 1977.

Richardson, R.C., \& Mortimer, K.P. Collective Bargaining and the Redefinition of Administrative Roles. Education Record, Vol. 49, No. 4, Fall, 1978.

Zirkel, P.A. In Search of the Meaning of Yeshiva. (AAHE-ERIC/Higher Education Research Current) AAHE Bulletin, Vol. 33, April, 1981. ED 197788. 